\title{
Reconstructing the North Atlantic atmospheric circulation in the 16th, 17th and 18th centuries from historical sources
}

\author{
Ricardo G arcía ${ }^{1}$, Luis Gimeno ${ }^{2, *}$, Emiliano Hernández ${ }^{1}$, Rosario Prieto ${ }^{3}$, \\ Pedro Ribera ${ }^{2}$
}

\author{
${ }^{1}$ Universidad Complutense de M adrid, Facultad de Ciencias Físicas, C iudad Universitaria, 28040 M adrid, Spain \\ ${ }^{2}$ Universidad de Vigo, Facultad de Ciencias de Orense, 32004 Orense, Spain \\ IIN A G LIA, Mendoza, Argentina
}

\begin{abstract}
This study presents the preliminary results obtained in the reconstruction of the North Atlantic atmospheric circulation during the 16th, 17th and 18th centuries using documental sources for the Spanish journeys to America kept in the 'Archivo General de Indias' (AGI). Sailing times were used as proxies for zonal atmospheric circulation. Two sample periods were studied: 1551 to 1650 and 1717 to 1737. Results show that the sailing time can be a good proxy to add to other proxy data sets. In addition, 12 possible tropical cyclones were identified during these 2 periods.
\end{abstract}

KEY WORDS: NAO $\cdot 16$ th to 18th centuries $\cdot$ Historical sources

\section{INTRODUCTION}

Climate variability on decadal and longer time scales is a major subject in climate research. With the concern about anthropogenic effects on global climate, there is a strong impetus to describe and understand the natural modes of variability in the climate system. A major source of interannual variability in atmospheric circulation is the North Atlantic Oscillation (NAO) (Lamb \& Peppler 1987).

NAO is a large-scale alternation of atmospheric mass between the North Atlantic regions of subtropical high surface pressure (centered near the Azores) and subpolar low surface pressure (south and east of Greenland). The alternation of mass can be characterized by 2 extremes: (1) high NAO: anomalously high subtropical surface pressure and anomalously low subpolar surface pressure, and (2) low NAO: the opposite surface pressure anomalies.

Changes in the surface pressure patterns result in changes in the mean circulation patterns over the North Atlantic. These changes are accompanied by

*Corresponding author. E-mail: I.gimeno@uvigo.es pronounced shifts in the storm tracks and associated synoptic eddy activity (WASA Group 1998). Changes in the mean and eddy components of the flow affect the transport of heat and moisture and can produce changes in regional patterns of temperature and precipitation. It has been established (Hurrell 1995) that during high extremes: (1) the westerlies onto Europe are over $8 \mathrm{~m} \mathrm{~s}^{-1}$ stronger than during low NAO winters, (2) there are cold winters in western Greenland and warm ones over much of the rest of Europe, and (3) drier conditions occur over southern Europe, the Mediterranean and Northern Africa, while higher precipitation occurs over Scandinavia. During low NAO extremes the anomalies are opposite.

The NAO variability during this century exhibits 3 main periods (Hurrell 1995). From the beginning of the century until about 1930 most of the winters were high NAO extremes. From the early 1940s until the early 1970s low NAO extremes were dominant, and since then high NAO extremes have occurred. However, it is necessary to study longer fluctuations in the climate of the Atlantic, so reconstruction of the NAO over the last 4 centuries has been a topic of intense interest in recent years. A way to do this is by means of early 


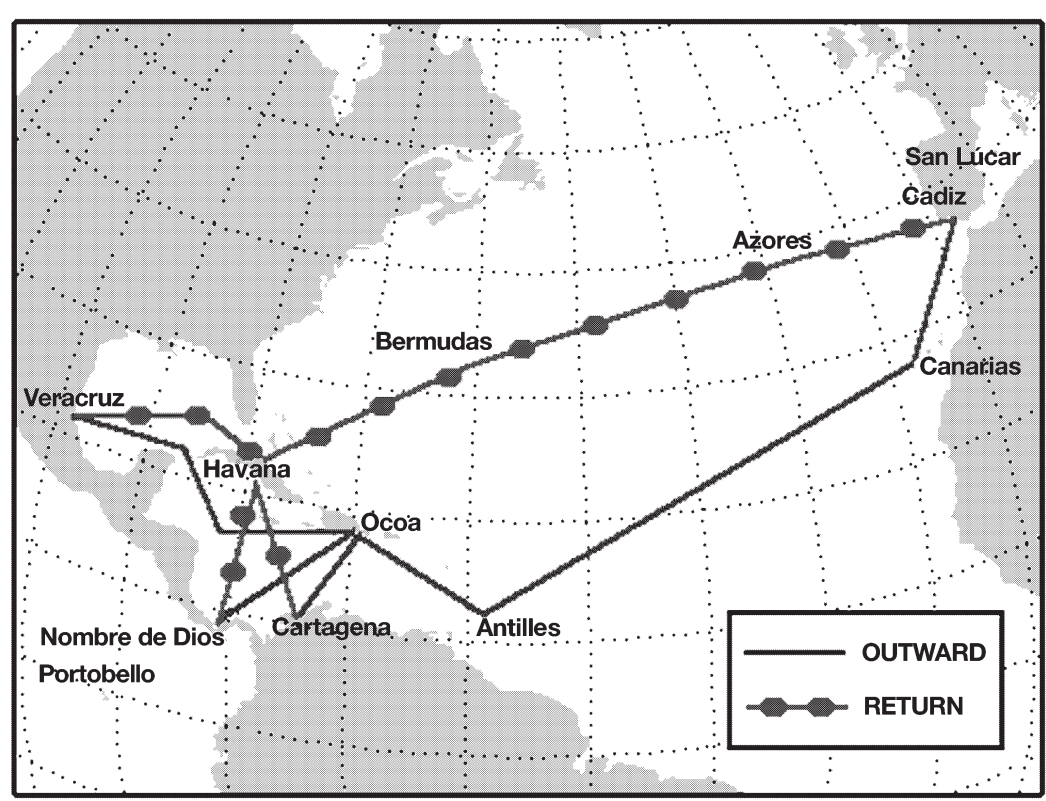

Fig. 1. Routes and main stops followed by Spanish ships crossing the Atlantic during the 16th, 17th and 18th centuries

accounts of oceanic climatic data in the world during the 16th, 17th and 18th centuries. There are more than 43000 logs that occupy 8 linear kilometers of shelves, with around 80000000 pages. The most important parts of the AGI concerning journeys were the 'Sección de Contratación', 'Sección de Indiferente General' and 'Sección de Arribadas'.

Among the documents belonging to the AGI, those documents related to the navigation between Central America and Spain were used. In the 16th to 17th centuries the Atlantic traffic was organized through a convoy system (Haring 1918, Laviana 1996): fleets. Two main fleets were organized yearly: (1) 'Flota de Nueva España', which sailed from Seville during the period April to August, with destination Veracruz (Mexico) via Santo Domingo (Dominican Republic), and (2) 'Galeones de Tierra Firme', which sailed from Seville between August

instrumental data ( ones et al. 1997, Luterbacher et al . 1999). However, if we want to know anything about the 16th or the first half of the 17th century, proxy data have to be used. Three ring chronologies (Cook et al. 1998) and ice-core data from Greenland (Appenzeller et al. 1998) show changes in the climate of the North A tlantic at decadal time scales probably related to fluctuations in the NAO.

The reconstruction of NAO behaviour during historical periods (non-instrumental) is a necessary step to better understand interesting topics such as the Little Ice Age (about 1550 to 1850 AD), atmospheric circulation variability (related to interannual NAO variability) and oceanic circulation variability (related to interdecadal NAO variability) (Hurrel \& van Loon 1997, Rowell et al. 1999, Shindell et al. 1999).

The objective of this paper is to show preliminary results of a multiyear project directed to reproduce the North Atlantic atmospheric circulation, especially $\mathrm{NAO}$, during the 16th, 17th and 18th centuries using historical documents from Spanish archives.

\section{DATA SOURCE}

Most of the data used in the project come from the 'Archivo General de Indias' (AGI), where the documents of the Spanish Administration in the American colonies are located. This archive represents the most important source of information from historical and November, with destination Portobello (Panama) via Cartagena de Indias (Colombia).

Fig. 1 shows the main routes. Each part of the journey is separately of interest climatologically. The journey from Spain to the Caribbean Sea could be a good index of the intensity of the trade winds; the journey through the Caribbean could help us to identify tropical cyclones. The duration of the return leg could be very useful to estimate the intensity of the westerlies and the NAO.

\section{METHOD OF CLIMATIC RECONSTRUCTION}

The main objective of this project is to find historical variability in the North Atlantic atmospheric circulation. To estimate this variability the outward and return journeys of fleets are used. The main data available were the dates of departure and arrival at the main ports.

The route from the Iberian Peninsula to A merica had 3 main stops: the Canary Islands, one of the Lesser Antilles and Ocoa in Puerto Rico (Fig. 1). From there, fleets could be directed to 3 ports: Cartagena, Portobello or Veracruz. For some of the journeys all the dates of arrival and departure at every stop are documented. In other cases only the dates of departure from the Iberian Peninsula and the date of arrival at one of the American ports are available. In a few cases no dates are documented. To homogenize data, the time 
from the Iberian Peninsula to Ocoa was estimated for all the journeys. If both dates (departure from Iberian Peninsula and arrival at Ocoa) were available, the time of the journey was calculated by subtraction. If the date of arrrival at one of the continental ports was available, but not the date of arrival at Ocoa, the time was calculated by deducting the average time from Ocoa to one of these ports (Ocoa-Cartagena: $6.5 \mathrm{~d}$; Ocoa-Portobello: $11.2 \mathrm{~d}$; and Ocoa-Veracruz: $20.8 \mathrm{~d}$ ). There was usually only 1 journey $\mathrm{yr}^{-1}$; however, if several journeys were available in the same year (less than $10 \%$ of the total sample), the average was calculated to establish an annual value. Therefore, the sailing time from the Iberian Peninsula to Ocoa was the proxy used to estimate the intensity of trade winds. It is necessary to consider that these data are subject to improvement by calculating the number of days that fleets stayed in the Canary Islands and the delay caused by any non-meteorological event. In this study, we only present the time from the Iberian Peninsula to Ocoa, since this improvement would be very labor intensive.

The return journey is treated in a similar way. Fleets could depart from Portobello, Cartagena or Veracruz, but Havana was a compulsory stop. So, the duration of the journey is calculated between Havana and the Iberian Peninsula. If not all the dates of departure and arrival were available, average times were used (Veracruz-Havana: 55 d; Portobello-Havana: 55 d; Cartagena-Havana: $12.5 \mathrm{~d}$ ). As for the outward journey, the time employed at intermediate stops (Bermudas or Azores) was not considered. This is not really a large mistake because it was almost the same for all the journeys, so the time between Havana and the Iberian Peninsula could be used as a proxy for the intensity of westerlies.

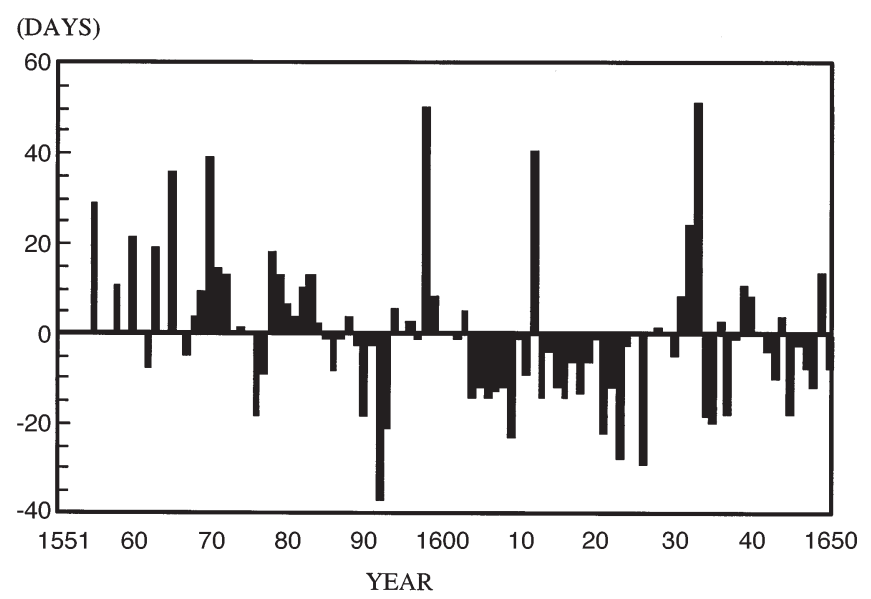

Fig. 2. Departures from the mean of the durations (d) for the journey between the Iberian Peninsula and Ocoa from 1551 to 1650

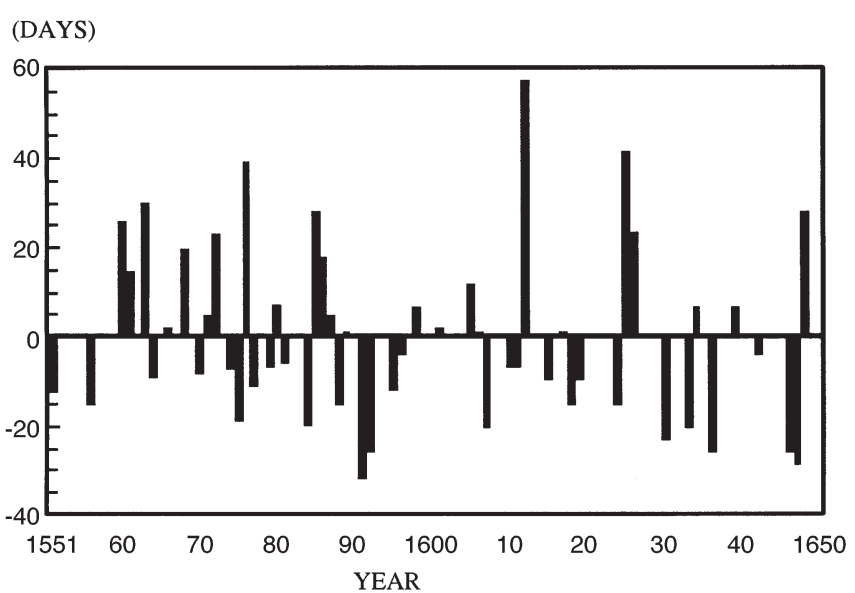

Fig. 3. Departures from the mean of the durations (d) for the journey between Havana and the Iberian Peninsula from 1551 to 1650

\section{PERIODS STUDIED}

In this study 2 periods were analyzed: 1551 to 1650 and 1717 to 1737 . The reason for choosing these 2 periods was the existence of 2 important references. Chaunu \& Chaunu (1955) studied with great detail the period 1551 to 1650 with the aim of calculating the commercial trade between Spain and America, and García Baquero (1976) performed a similar study for the period 1717 to 1737 . These 2 studies helped us to locate the AGI logs containing information about the transatlantic journeys.

\section{RESULTS OF THE PRELIMINARY STUDY}

\subsection{0 to 1650}

Fig. 2 shows the departures from the mean for the durations of the journey between the Iberian Peninsula and Ocoa. It was possible to estimate the journey durations in 81 of the 100 years. The mean duration in these 81 years was $59.2 \mathrm{~d}$ with $110 \mathrm{~d}$ as the highest value and $22.4 \mathrm{~d}$ as the lowest. The standard deviation was $17 \mathrm{~d}$. The large variability in Fig. 2 is not entirely caused by the variable intensity of the trade winds because there are some features (delays, hazards, etc.) that are only partially identified.

In Fig. 3 the departures from the mean for the durations of the journey between Havana and the Iberian Peninsula are displayed. In this case it was only possible to calculate durations for 52 of the 100 years analyzed. However, the logs used were only a small fraction of the huge quantity of AGI logs referring to transatlantic journeys. The average duration of this journey was $69 d$, the standard deviation was $20 d$ and 
(DAYS)

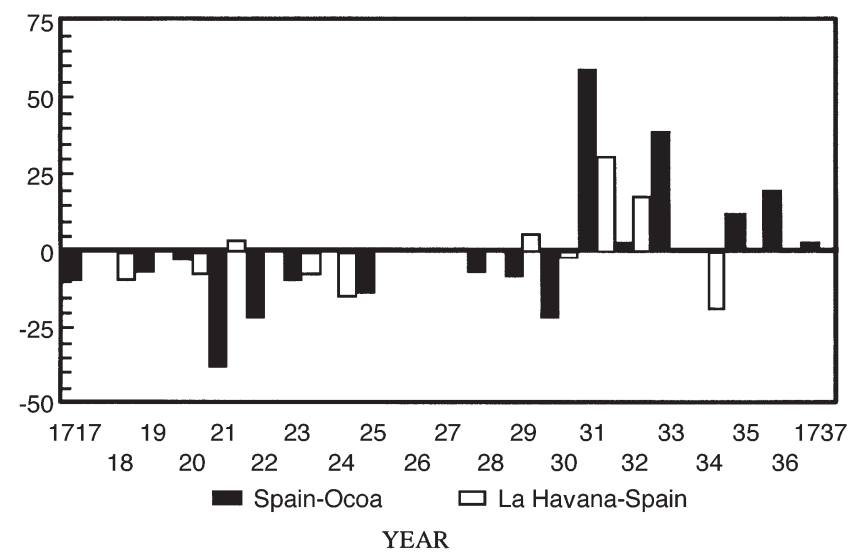

Fig. 4. Departures from the mean of the durations (d) for the journey Spain-Ocoa and La Havana-Iberian Peninsula from 1717 to 1737

the highest and lowest values were 126 and $37 \mathrm{~d}$, respectively. A better estimation of the time taken in stops and delays due to non-meteorological reasons would increase the confidence regarding our estimation of westerly intensities during this period.

\subsection{7 to 1737}

Fig. 4 shows the departure from the mean for the durations of the journeys between the Iberian Peninsula and Ocoa and between Havana and the Iberian Peninsula. For the outward journey (Iberian Peninsula-Ocoa) information was available for $16 \mathrm{yr}$. The mean was $63 \mathrm{~d}$, the standard deviation $24 \mathrm{~d}$ and the highest and lowest values 122.2 and 25.2 d, respectively. For the return journey only 11 years are available. The average duration of the journey was $55 \mathrm{~d}$, the standard deviation $14.5 \mathrm{~d}$ and the highest and lowest values 86 and $36 \mathrm{~d}$, respectively.

Considering both periods, there were only 51 years in which outward and return sailing times were available. The correlation ( $r=0.24)$ between both times was not significantly different from zero.

\section{OTHER SOURCES OF INFORMATION}

The journey durations presented above can be dramatically improved as proxy data for Atlantic atmospheric circulation in the following ways: (1) Using fleets data, but considering the whole volume of logs concerning them. This would permit us to discount the time of stops and the delays due to non-meteorological reasons. (2) Using 'navios sueltos', which were those ships not included in the fleets and whose number was large every year. (3) Using 'avisos', which were mail ships whose single task was communication between the Iberian Peninsula and America. These ships did not make any intermediate stop and consequently the durations of the journeys are the best-quality data for the period when 'avisos' were active (16th century). The number of 'avisos' were also very high every year; they were replaced by the 'Royal Mail ship Service' in the 17th century. (4) Using 'Royal Mail ships', a regular service that started in 1628 and lasted $300 \mathrm{yr}$. The periodicity of these journeys was every 3 mo during the 17th century and every month during the 18th and 19th centuries. All the logbooks, containing daily information about the position, intensity of wind and meteorological events, are available. These ships represent, without any doubt, the best source of marine climatic data from the Atlantic during the covered period. An example of the climatic reconstruction performed with information pertaining to one of the mail ships for the year 1775 can be found in García et al. (2000).

\section{OTHER INFORMATION FROM HISTORICAL DOC UMENTS: POSITIONS OF TROPICAL CYCLONES}

Although the main objective of our work was to reproduce the Atlantic atmospheric circulation from the Spanish ships that crossed the Atlantic during the 16th, 17th and 18th centuries, it is also convenient to check these documental sources with the possibility of identifying tropical cyclones. Without doing a systematic search, 12 shipwrecks produced by strong storms were reliably identified (date and position) in the Caribbean area during our sample periods: 1551 to 1650 and 1717 to 1737 (Fig. 5).

The quantity of details about these events differ widely from one event to another. Some of them are written with extraordinary detail, such as the shipwreck that happened on 15 J uly 1733 . The captain of one of the few ships that was not sunk described the event from $24 \mathrm{~h}$ before and indicated what the weather was like for each hour and the effects on the other ships forming the fleet. M ore than 10 pages were written to describe the event in this captain's report.

A sound search through all the documents concerning fleets, 'navios sueltos', 'avisos' and 'Royal Mail ships' would permit us to register many tropical cyclones not identified at present.

\section{CONCLUDING REMARKS}

In this study, it is shown that the information provided by the Spanish ships crossing the Atlantic during 

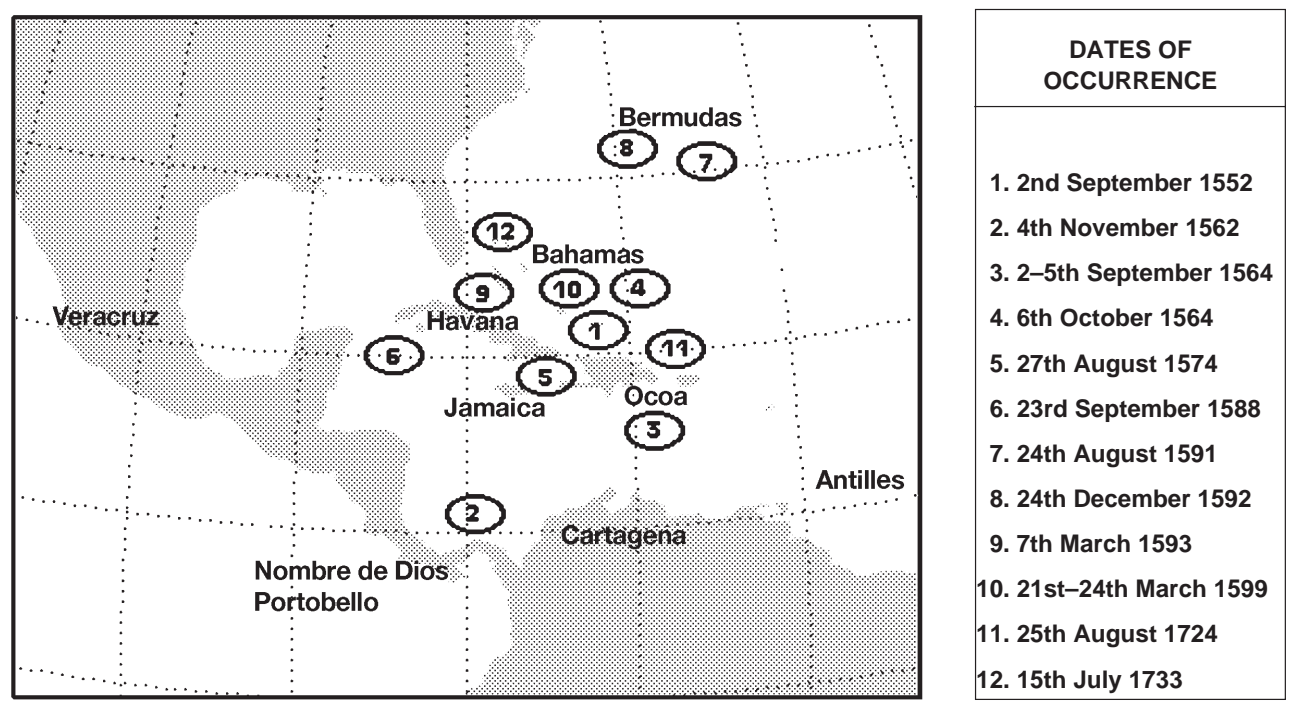

Fig. 5. Dates and positions of shipwrecks probably produced by tropical cyclones during the periods 1551 to 1650 and 1717 to 1737

the 16th, 17th and 18th centuries can be of great interest in reproducing the North Atlantic atmospheric circulation and in identifying tropical cyclones.

Acknowledgements. We would like to thank an anonymous reviewer, whose comments helped us to improve the manuscript.

\section{LITERATURE CITED}

Appenzeller C, Stocker TF, Anklin M (1998) North Atlantic Oscillation dynamics recorded in Greenland ice cores. Science 282:446-449

Chaunu H, Chaunu P (1955) Séville et l'Atlantique (1504-1650). Centre de Recherches Historiques, Paris

Cook ER, Dárrigo RD, Briffa KR (1998) A reconstruction of the North Atlantic Oscillation using tree-ring chronologies from North America and Europe. Holocene 8:9-17

García R, Prieto M R, López A, Hernández E, Gimeno L, Herrera $R$ (2000) The Archivo General de Indias (AGI): a source of surface marine climatological information. WM O Technical Report, WMO, Geneva (in press)

García Baquero A (1976) Cadiz y el Atlantico (1717-1778). Escuela de Estudios Hispano-Americanos, Seville

Haring CH (1918) Trade and navigation between Spain and

Editorial responsibility: Hans von Storch,

Geesthacht, Germany the Indies in the time of the Hapsburgs. Harvard Univ Press, Cambridge

Hurrell J W (1995) Decadal trends in the North Atlantic Oscillation: regional temperatures and precipitation. Science 269:676-679

Hurrell J W, Van Loon H (1997) Decadal variations in climate associated with the North Atlantic Oscillation. Clim Change 36:301-326

J ones PD, J onsson T, Wheeler D (1997) Extension to the North Atlantic Oscillation using early instrumental pressure observation from Gibraltar and South-West Iceland. Int J Climatol 17:1433-1450

Lamb P, Peppler RA (1987) N orth Atlantic Oscillation: concept and an application. Bull Am M eteorol Soc 68:1218-1225

Laviana ML (1996) La America Española, 1492-1898. Temas de Hoy, Madrid

Luterbacher J, Schmutz C, Gyalistras D, Xoplaki E, Wanner H (1999) Reconstruction of monthly NAO and EU indices back to AD 1675. Geophys Res Lett 26:2745-2749

Rowell MJ et al. (1999) Oceanic forcing of the wintertime North Atlantic Oscillation and European climate. Nature 398:320-323

Shindell DT, Miller RL, Schmidt G, Pandolfo L (1999) simulation of recent northern winter climate by greenhouse-gas forcing. Nature 399:452-455

WASA group (1998) Changing waves and storms in the Northeast Atlantic. Bull Am M eteorol Soc 79:741-760

Submitted: October 4, 1999; Accepted: December 4, 1999 Proofs received from author(s): February 7, 2000 